\title{
Removal of Phosphorus from Livestock Effluents
}

\section{Ariel A. Szogi* and Matias B. Vanotti USDA-ARS}

For removal of phosphorus (P) from swine liquid manure before land application, we developed a treatment process that produces low $\mathrm{P}$ effluents and a valuable $\mathrm{P}$ by-product with minimal chemical addition and ammonia losses. The new wastewater process included two sequential steps: (i) biological nitrification and (ii) increasing the $\mathrm{pH}$ of the nitrified wastewater to precipitate $\mathrm{P}$. We hypothesized that by reduction of inorganic buffers $\left(\mathrm{NH}_{4}^{+}\right.$and carbonate alkalinity) via nitrification, $\mathrm{P}$ could be selectively removed by subsequent hydrated lime $\left[\mathrm{Ca}(\mathrm{OH})_{2}\right]$ addition. The objective of the study was to assess if this new treatment could consistently reduce inorganic buffer capacity with varied initial concentrations of $\mathrm{N}(100-723 \mathrm{mg}$ $\left.\mathrm{NH}_{4}^{+} \mathrm{L}^{-1}\right), \mathrm{P}\left(26-85 \mathrm{mg} \mathrm{TP} \mathrm{L}^{-1}\right)$, and alkalinity (953-3063 mg $\mathrm{CaCO}_{3} \mathrm{~L}^{-1}$ ), and then efficiently remove $\mathrm{P}$ from swine lagoon liquid. The process was tested with surface lagoon liquids from 10 typical swine farms in North Carolina. Each lagoon liquid received treatment in a nitrification bioreactor, followed by chemical treatment with $\mathrm{Ca}(\mathrm{OH})_{2}$ at $\mathrm{Ca}$ rates of $0,2,4,6$, 8,10 , and $12 \mathrm{mmol} \mathrm{L}^{-1}$ to precipitate $\mathrm{P}$. This configuration was compared with a control that received the same $\mathrm{Ca}$ rates but without the nitrification pretreatment. The new process significantly reduced $>90 \%$ the inorganic buffers concentrations compared with the control and prevented ammonia losses. Subsequent lime addition resulted in efficient $\mathrm{pH}$ increase to $\geq 9.5$ for optimum $\mathrm{P}$ precipitation in the nitrified liquid and significant reduction of effluent total $\mathrm{P}$ concentration versus the control. With this new process, the total $\mathrm{P}$ concentration in treated liquid effluent can be adjusted for on-farm use with up to $>90 \%$ of P removal. The recovered solid Ca phosphate material can be easily exported from the farm and reused as $\mathrm{P}$ fertilizer. Therefore, the new process can be used to reduce the $\mathrm{P}$ content in livestock effluents to levels that would diminish problems of excess $\mathrm{P}$ accumulation in waste-amended soils.

Copyright $\odot 2009$ by the American Society of Agronomy, Crop Science Society of America, and Soil Science Society of America. All rights reserved. No part of this periodical may be reproduced or transmitted in any form or by any means, electronic or mechanical, including photocopying, recording, or any information storage and retrieval system, without permission in writing from the publisher.

Published in J. Environ. Qual. 38:576-586 (2009). doi:10.2134/jeq2007.0641

Received 12 Dec. 2007.

*Corresponding author (Ariel.Szogi@ARS.USDA.GOV).

(c) ASA, CSSA, SSSA

677 S. Segoe Rd., Madison, WI 53711 USA
$\mathrm{R}$ ESEARCH efforts on P removal from liquid manure before land application have dealt mostly with chemical precipitation techniques that extract $\mathrm{P}$ from manure liquid and convert the extracted P into a useful product (Greaves et al., 1999). Thus, P can be removed and recovered as phosphate precipitate by adding Fe and Al (Loehr et al., 1976), Mg (Liberti et al., 1986; Burns et al., 2001; Nelson et al., 2003; Parent et al., 2007), or Ca (House, 1999) compounds. However, implementation of these techniques for liquid manure treatment has been slow due to technical limitations such as the large demand for added chemicals (Celen et al., 2007); the limited value of by-products such as $\mathrm{Al}$ or $\mathrm{Fe}$ phosphates (Loehr et al., 1976); or potential ammonia gas volatilization losses during a $\mathrm{P}$ extraction process, such as the precipitation of $\mathrm{Mg}$ ammonium phosphate (Westerman and Bicudo, 2000).

Reindl (2007) classified techniques for P removal from wastewater and manure by precipitation of Ca phosphate into three groups: crystallizers, fluid bed reactors, and the new process used in this study. Crystallizers and fluid bed reactors have the technical limitations of requiring a seeding material (e.g., sand or rock phosphate grains) and a substantial amount of chemical addition to precipitate P. Phosphorus removal efficiencies for crystallizers and fluid bed reactors are reported to be $<80 \%$ (Seckler et al., 1996; Valsami-Jones, 2001; Bowers et al., 2007). To solve these technical limitations, a wastewater treatment technology was developed to remove P from liquid manure with minimal chemical addition and to produce a valuable by-product (Vanotti et al., 2005b). The processes involved in the new technology include (i) biological nitrification of liquid manure to oxidize ammonium $\left(\mathrm{NH}_{4}^{+}\right)$to nitrate $\left(\mathrm{NO}_{3}^{-}\right)$, (ii) reduction of natural buffers, and (iii) increasing the $\mathrm{pH}$ of the nitrified wastewater through addition of $\mathrm{Ca}$ or $\mathrm{Mg}$ hydroxide to precipitate $\mathrm{P}$ (Vanotti et al., 2003; Vanotti et al., 2005a). Because $\mathrm{NH}_{4}^{+}$is mostly converted to $\mathrm{NO}_{3}^{-}$, increased $\mathrm{pH}$ during $\mathrm{P}$ precipitation does not result in significant gaseous $\mathrm{N}$ loss in ammonia gas form. The final product is a $\mathrm{Ca}$ phosphate-rich sludge that can be used as P fertilizer (Vanotti et al., 2003; Szogi et al., 2006; Bauer et al., 2007).

In North Carolina, manure generated during swine production has been traditionally handled using anaerobic lagoons and subsequent effluent disposal through land applications (Barker, 1996); however, by law, the construction of all new swine farms requires alternative systems without lagoons (NC General Assembly, 2007). The new P

A.A. Szogi, and M.B. Vanotti, USDA-ARS Coastal Plains Soil, Water and Plant Research Center, 2611 W. Lucas St., Florence, SC 29501-1242. Mention of a specific product or vendor does not constitute a guarantee or warranty of the product by the U.S. Department of Agriculture or imply its approval to the exclusion of other products that may be suitable.

Abbreviations: $\mathrm{CaR}$, calcium application rate; $C O D$, chemical oxygen demand; $T K N$, total Kjeldahl N; PT, pretreatment; TP, total P. 
removal technology was conceived to remove $\mathrm{P}$ in systems with lagoons and systems without lagoons (Vanotti et al., 2005b). In the systems without lagoons, raw liquid manure is treated through an enhanced solid-liquid separation process with polymers to remove most of the carbonaceous material from the wastewater. The separated water is then treated with the nitrification and soluble $\mathrm{P}$ removal sequence. A denitrification tank can also be incorporated into the treatment system to provide total $\mathrm{N}$ removal in addition to the P removal. This configuration was tested in a full-scale study at a finishing swine farm in North Carolina (Vanotti et al., 2007). In the systems with lagoons, the anaerobically digested supernatant liquid, rich in $\mathrm{NH}_{4}-\mathrm{N}$ and alkalinity but low in organic buffers of $\mathrm{pH}$, is nitrified, and $\mathrm{P}$ is subsequently removed by adding hydrated lime. The effectiveness of the technology was tested in a pilot field study at a nursery swine farm in North Carolina, where 95 to $98 \%$ of the $\mathrm{P}$ was precipitated from the anaerobic lagoon effluent. Phosphorus recovered from the effluent (Ca phosphate) consisted of 16 to $17 \% \mathrm{P}_{2} \mathrm{O}_{5}$ (Vanotti et al., 2003).

It was unclear if with this process the high $\mathrm{P}$ removal efficiency is consistent across diverse types of swine farms because the chemical characteristics of lagoon liquid effluents vary considerably from farm to farm. Because nitrifying bacteria are autotrophic microorganisms that consume $\mathrm{NH}_{4}^{+}$and carbonate alkalinity, we hypothesized that, by reduction of these buffer compounds via nitrification, $\mathrm{P}$ could be selectively removed by subsequent hydrated lime addition. Therefore, the objective of the present study was to assess if this new process technology could consistently reduce $\mathrm{NH}_{4}^{+}$and carbonate alkalinity and efficiently remove $\mathrm{P}$ from swine lagoon liquid with varied initial N, P, and alkalinity concentrations. For this purpose, a laboratory study was performed using lagoon liquid from 10 swine production units that included different types of swine production operations in North Carolina. The testing was performed in the lagoon effluents of these facilities before land application.

\section{Materials and Methods}

\section{Theoretical Background}

Liquid swine manure is a mixture of urine, water, and feces. Livestock urine usually contains more than $55 \%$ of the excreted $\mathrm{N}$, of which more than $70 \%$ is in the form of urea (Sommer and Husted, 1995). Hydrolysis of urea by the enzyme urease produces $\mathrm{NH}_{4}^{+}$and carbonate according to the following reaction:

$$
\mathrm{CO}\left(\mathrm{NH}_{2}\right)_{2}+2 \mathrm{H}_{2} \mathrm{O} \rightarrow 2 \mathrm{NH}_{4}^{+}+\mathrm{CO}_{3}^{2-}
$$

Therefore, a large part of the inorganic carbon in liquid manure is produced during decomposition of organic compounds. Although the remaining organic compounds contribute to the buffering capacity in liquid manure, carbonate and $\mathrm{NH}_{4}^{+}$ alkalinity are the most important chemical components in liquid manure. They contribute to the buffering capacity in the alkaline $\mathrm{pH}$ range (Fordham and Schwertmann, 1977; Sommer and Husted, 1995). Alkaline $\mathrm{pH}$ is necessary to form a P precipitate with $\mathrm{Ca}$ and $\mathrm{Mg}$ compounds (House, 1999). When a Ca or $\mathrm{Mg}$ hydroxide is added to liquid manure, the hydroxide reacts with the existing bicarbonate to form carbonate, with $\mathrm{NH}_{4}^{+}$to form ammonia $\left(\mathrm{NH}_{3}\right)$, and with phosphate to form phosphate precipitate compounds (Loehr et al., 1976; Tchobanoglous and Burton, 1991). For instance, using Ca hydroxide as an example, the following equations define the reactions:

$$
\begin{aligned}
& \mathrm{Ca}(\mathrm{OH})_{2}+\mathrm{Ca}\left(\mathrm{HCO}_{3}\right)_{2} \rightarrow 2 \mathrm{CaCO}_{3} \downarrow+2 \mathrm{H}_{2} \mathrm{O} \\
& 5 \mathrm{Ca}^{2+}+4 \mathrm{OH}^{-}+3 \mathrm{HPO}_{4}=\rightarrow \mathrm{Ca}_{5} \mathrm{OH}\left(\mathrm{PO}_{4}\right)_{3} \downarrow+3 \mathrm{H}_{2} \mathrm{O}
\end{aligned}
$$

The reaction in Eq. [2] is complete at $\mathrm{pH} \geq 9.5$, whereas that of Eq. [3] starts at $\mathrm{pH}>7.0$, but the reaction is very slow at $\mathrm{pH} \leq 9.0$. As the $\mathrm{pH}$ value of the wastewater increases beyond 9.0, excess $\mathrm{Ca}$ ions react with the phosphate to precipitate as Ca phosphate (Eq. [3]). Not expressed in Eq. [2] is the fact that in wastewater containing high $\mathrm{NH}_{4}^{+}$concentration, large amounts of lime are required to elevate the $\mathrm{pH}$ to required values because $\mathrm{NH}_{4}^{+}$reaction tends to neutralize the hydroxyl ions according to Eq. [4]:

$$
\mathrm{Ca}(\mathrm{OH})_{2}+2 \mathrm{NH}_{4}^{+} \rightarrow 2 \mathrm{NH}_{3} \uparrow+\mathrm{Ca}^{2+}+2 \mathrm{H}_{2} \mathrm{O}
$$

Consequently, precipitation of phosphate in animal wastewater using an alkaline compound such as lime is very difficult due to the inherent high buffering capacity of liquid manure $\left(\mathrm{NH}_{4}-\mathrm{N}\right.$ $\geq 200 \mathrm{mg} \mathrm{L}^{-1}$ and alkalinity $\geq 1200 \mathrm{mg} \mathrm{L}^{-1}$ ). The buffer effect prevents rapid changes in $\mathrm{pH}$. However, this problem is solved using a prenitrification step that reduces the concentration of $\mathrm{NH}_{4}^{+}$(Eq. [5]) and bicarbonate alkalinity (Eq. [6]) (Vanotti et al., 2005b):

$$
\begin{aligned}
& \mathrm{NH}_{4}^{+}+2 \mathrm{O}_{2} \rightarrow \mathrm{NO}_{3}^{-}+2 \mathrm{H}^{+}+\mathrm{H}_{2} \mathrm{O} \\
& \mathrm{HCO}_{3}^{-}+\mathrm{H}^{+} \rightarrow \mathrm{CO}_{2} \uparrow+\mathrm{H}_{2} \mathrm{O}
\end{aligned}
$$

The buffering effect of $\mathrm{NH}_{4}^{+}$(Eq. [4]) is reduced by biological nitrification of the $\mathrm{NH}_{4}^{+}$(Eq. [5]). Simultaneously, the buffering effect of bicarbonate (Eq. [2]) is greatly reduced with the acid produced during nitrification (Eq. [6]). These two simultaneous reactions leave a less buffered liquid in optimum $\mathrm{pH}$ conditions for phosphate removal with the addition of small amounts of lime (Eq. [3]).

\section{Anaerobic Lagoons}

Liquid manure was collected from 10 anaerobic lagoons located in swine-producing counties of North Carolina. The lagoons were selected using farm information on number and category of animals, surface characteristics of the lagoons, and waste analysis reports obtained from the North Carolina Department of Agriculture, Agronomic Division, Raleigh, NC. The sampled lagoons treated and stored manure from different sizes and types of swine production facilities, such as breeding, nursery, and finishing operations (Table 1). Two 20-L samples per lagoon were collected at approximately $0.30-\mathrm{m}$ below the liquid surface and conveyed into 25-L plastic containers using a pump. The pump had an intake that was a long plastic tubing attached along a 4-m long $(5.1-\mathrm{cm}$ diam.) plastic pipe with a float on one end. The float maintained the intake below the liquid surface and away from the lagoon banks. Samples were sealed, packed on ice, transported to the lab, and stored at $<4^{\circ} \mathrm{C}$ until they were analyzed and used in the experiments within a week of being collected. 
Table 1. Swine operations in North Carolina with anaerobic lagoons used in the tests.

\begin{tabular}{|c|c|c|c|c|}
\hline Farm no. & Location & Operation type & No. of pigs & Surface lagoon observations $\ddagger$ \\
\hline 1 & Duplin Co. & nursery & 2600 & dark purple/black color \\
\hline 2 & Duplin Co. & finishing & 640 & dark purple/black color \\
\hline 3 & Sampson Co. & finishing & 3500 & shallow and wide lagoon \\
\hline 4 & Duplin Co. & nursery & 3600 & dark brown color \\
\hline 5 & Onslow Co. & finishing & 3670 & pink color \\
\hline 6 & Onslow Co. & breeding & 3200 & greenish color, no smell. \\
\hline 7 & Onslow Co. & finishing & 2520 & pink color \\
\hline 8 & Onslow Co. & nursery & 3840 & black color, strong ammonia smell \\
\hline 9 & Wake Co. & research & 250 & dark purple color \\
\hline 10 & Sampson Co. & finishing & 3500 & dark brown color \\
\hline
\end{tabular}

† Nursery farms were weaner to feeder operations growing pigs from 5.5 to $23 \mathrm{~kg}$ weight. Finishing farms were feeder to finish operations growing pigs from 23 to $110-115 \mathrm{~kg}$ weight. Breeding farm had 3200 sows weighing $180-230 \mathrm{~kg}$ from farrow to wean. Research facility had 250 sows (farrow to wean), and half of the weaned pigs were grown to market weight at the site.

₹ All lagoons are single-stage (primary) anaerobic lagoons, except the lagoon in farm number 6, which was the third lagoon in a three-stage lagoon system.

\section{Basic Process Configuration}

The study consisted of 10 consecutive experiments using the basic process configuration shown in Fig. 1 to treat 10 lagoon liquids. In each experiment, swine wastewater received biological treatment in a nitrification bioreactor, followed by chemical treatment with $\mathrm{Ca}(\mathrm{OH})_{2}$ in a $\mathrm{P}$ separation reactor to precipitate phosphate. This configuration was compared with a control representing a control method that received chemical treatment with $\mathrm{Ca}(\mathrm{OH})_{2}$ but without the nitrification pretreatment. All control and nitrified lagoon liquids were treated with $\mathrm{Ca}(\mathrm{OH})_{2}$ applied at rates of $0,2,4,6,8,10$, and $12 \mathrm{mmol} \mathrm{Ca}$ $\mathrm{L}^{-1}$ of lagoon liquid. Each experiment was run twice, and all analyses were performed in duplicate.

\section{Nitrification Treatment}

Fluidized bed biological reactors were used for the nitrification step. These reactors were constructed and operated as described by Vanotti and Hunt (2000). A culture of acclimated lagoon nitrifying sludge was prepared with seed biofilm sludge obtained from the surface horizon of an overland flow treatment plot that treated the effluent from an anaerobic swine lagoon in Duplin Co., NC (Vanotti and Hunt, 2000; Szogi et al., 2004). The reactors contained the acclimated lagoon nitrifying sludge immobilized in a supporting porous medium that consisted of pellets (cubes that were 3- to 5-mm per side) made of polyvinyl alcohol polymer according to the polyvinyl alcohol-freezing method described by Vanotti and Hunt (2000). The nitrifying pellets increased the bacteria population in the reactor vessel (150 $\mathrm{g}$ of pellets per L-reactor), which reduced total nitrification treatment time. However, the support medium per se is not critical, and other biological nitrification methods are equally suitable, provided that the nitrifying bacteria are acclimated to wastewater with a high $\mathrm{NH}_{4}-\mathrm{N}$ concentration (Szogi et al., 2004).

Process temperature was set at $30^{\circ} \mathrm{C}$ using a heat regulator with a re-circulating water bath that accommodated up to six 1.2-L volume reactors. An aerator provided fine-bubble aeration at a flow rate of $0.6 \mathrm{~L} \mathrm{~min}^{-1}$ and fluidization of the support medium; the resulting average dissolved oxygen concentration in the mixed liquor was about $4.3 \mathrm{mg} \mathrm{L}^{-1}$, as measured with an oxygen meter (Model 52; YSI, Yellow Spring, OH). The nitrifying activity of the reactor was calculated from the rate of increase of $\mathrm{NO}_{3}-\mathrm{N}$ concentration during the first $4 \mathrm{~h}$ of aeration. The nitrification rate was $11 \pm 4 \mathrm{mg} \mathrm{N} \mathrm{L}^{-1}$ reactor $\mathrm{h}^{-1}$, or $259 \mathrm{mg} \mathrm{N} \mathrm{L}^{-1}$ reactor $\mathrm{d}^{-1}$. Alkalinity was monitored during the nitrification process, and aeration was terminated when $>90 \%$ of the natural alkalinity was consumed. The nitrified effluent was transferred to glass reaction vessels where it was chemically treated for P removal with lime.

\section{Phosphorus Precipitation with Lime}

Lime was applied to each nitrified effluent at rates of 2, 4, 6, 8,10 , and $12 \mathrm{mmol} \mathrm{Ca} \mathrm{L}{ }^{-1}$ of effluent $[1 \mathrm{mmol} \mathrm{Ca}=74.1 \mathrm{mg}$ $\left.\mathrm{Ca}(\mathrm{OH})_{2}\right]$ using lime suspensions in water. Identical lime treatments were applied to the control in which the nitrification step was omitted. The lime was a commercial, high-purity hydrated lime powder, containing $98.5 \% \mathrm{Ca}(\mathrm{OH})_{2}$, with a mean particle size of $3.5 \mu \mathrm{m}$ (Codex Hydrated Lime; Mississippi Lime Co., Alton, IL). Aliquots of nitrified or control liquid $(35 \mathrm{~mL})$ were transferred to $50-\mathrm{mL}$ glass tubes to be reacted with lime. After lime application, the liquid was mixed with a stirrer for $1 \mathrm{~min}$, and the precipitate was allowed to settle for $0.5 \mathrm{~h}$. Treated wastewater was sampled in the supernatant after the 0.5 -h sedimentation period and analyzed for total $\mathrm{P}$ to determine the removal efficiency. Phosphorus removal performance was determined by the difference between the total P concentration in the treated effluent and that of the original wastewater sample. The precipitate was filtered with glass microfiber filters (Whatman 934-AH; Whatman Inc., Clifton, NJ), dried and weighed to measure the amount of solid produced, and digested with acid to determine inorganic $\mathrm{P}$ content. All the precipitation tests were performed in duplicate.

\section{Ammonia Volatilization Losses}

The effect of $\mathrm{pH}$ on $\mathrm{N}$ losses by ammonia $\left(\mathrm{NH}_{3}\right)$ volatilization was determined in nitrified and non-nitrified lagoon samples of lagoon 1 by adding $\mathrm{NaOH}$ to reach $\mathrm{pH}$ values of $6,7,8,9,10$, and 11 and measuring remaining total inorganic $\mathrm{N}\left(\mathrm{NH}_{4}-\mathrm{N}\right.$ plus $\left.\mathrm{NO}_{3}-\mathrm{N}\right)$ in the liquid. For each target $\mathrm{pH}$, a separate aliquot of nitrified or control lagoon liquid $(150 \mathrm{~mL})$ was transferred to a $250-\mathrm{mL}$ Erlenmeyer flak to be reacted with $0.1 \mathrm{~mol} \mathrm{~L}^{-1} \mathrm{NaOH}$. The experiment was run in duplicate. 


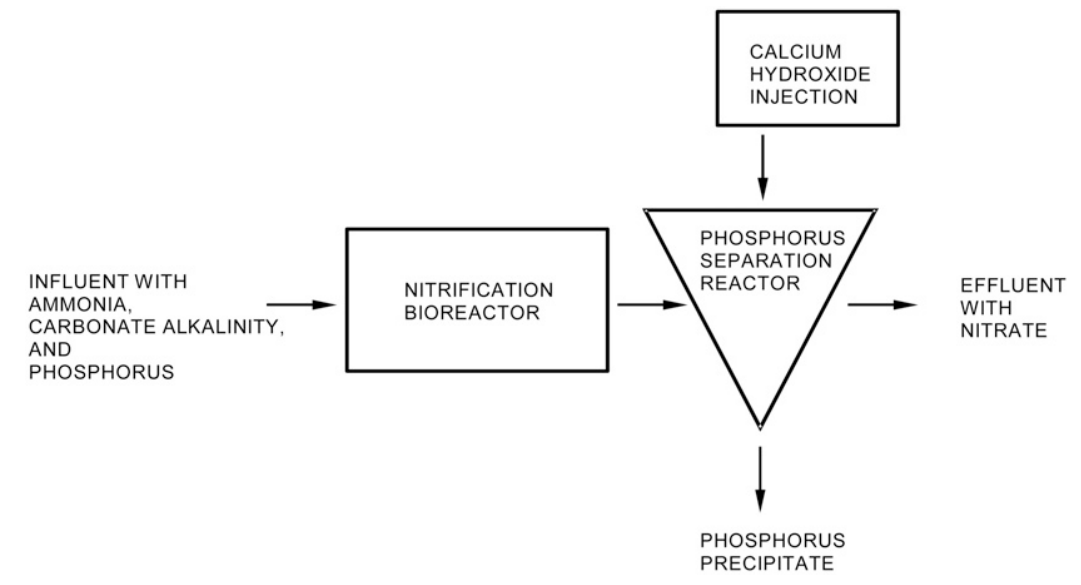

Fig. 1. Schematic of the P removal process from swine lagoon liquid.

\section{Study of Natural Buffers}

The effect of natural buffer reduction on the amount of alkali needed to optimize process $\mathrm{pH}$ for $\mathrm{P}$ removal was evaluated using liquid from lagoons 1 and 2 (Table 2). The tests compared the addition of alkali in three experiments: (i) addition of alkali to liquid swine manure with carbonate alkalinity removed, (ii) addition of alkali to liquid swine manure with $\mathrm{NH}_{4}^{+}$and carbonate alkalinity removed, and (iii) the same addition of alkali to the original liquid swine manure with its natural buffers intact (control). The first experiment used acidification with $0.1 \mathrm{~mol} \mathrm{~L}^{-1} \mathrm{HCl}$ to $\mathrm{pH} 3.0$ to remove the carbonate alkalinity (Eq. [5]), and the second experiment used nitrification to remove $\mathrm{NH}_{4}^{+}$and carbonate alkalinity (Eq. [5] and Eq. [6]). Each test consisted of $20 \mathrm{~mL}$ of acidified, nitrified, or control liquid placed in 100-mL beakers to which standardized $0.1 \mathrm{~N} \mathrm{NaOH}$ was added in a stepwise fashion until $\mathrm{pH} 12.0$ was reached. All tests were performed in duplicate.

\section{Analytical Methods}

Wastewater analyses were performed according to APHA standard methods (APHA, AWWA, and WEF, 1998). Total alka- linity was determined by acid titration to the bromocresol green endpoint ( $\mathrm{pH}$ 4.5) and expressed as $\mathrm{mg} \mathrm{CaCO}_{3} \mathrm{~L}^{-1}$. This $\mathrm{pH}$ coincided with the inflection point of the titration curve. The orthophosphate $\left(\mathrm{PO}_{4}-\mathrm{P}\right)$ fraction, also termed soluble $\mathrm{P}$, was determined by the automated ascorbic acid method (Standard Method 4500-P F) after filtration through a $0.45-\mu \mathrm{m}$ membrane filter (Gelman type Supor-450; Pall Corp., Ann Arbor, MI). The same filtrate was used to measure $\mathrm{NH}_{4}-\mathrm{N}$ by the automated phenate method (Standard Method $4500-\mathrm{NH}_{3} \mathrm{G}$ ) and $\mathrm{NO}_{3}-\mathrm{N}$ by the automated Cd reduction method (Standard Method 4500- $\mathrm{NO}_{3}-$ F). Total P (TP) and total Kjeldahl N (TKN) were determined using the ascorbic acid method and the phenate method, respectively, adapted to Kjeldahl digested extracts (Pote and Daniel, 2000). Total solids (TS) were determined after drying the liquid samples at $105^{\circ} \mathrm{C}$ (Standard Method $2540 \mathrm{~B}$ ). Total suspended solids and volatile suspended solids were determined gravimetrically after filtration using glass micro-fiber filters and drying to constant mass at $105^{\circ} \mathrm{C}$ for total suspended solids and further ignited to $500^{\circ} \mathrm{C}$ for volatile suspended solids (standard method 2540 D). Chemical oxygen demand (COD) was determined by the closed reflux colorimetric method (Standard Method 5520 D). Lagoon liquid samples were block-digested using nitric acid

Table 2. Lagoon liquid characteristics†

\begin{tabular}{|c|c|c|c|c|c|c|c|c|c|c|c|c|c|}
\hline $\begin{array}{l}\text { Lagoon } \\
\text { no. }\end{array}$ & $\mathrm{pH}$ & TP & $\begin{array}{c}\text { Soluble } \\
\text { P }\end{array}$ & TKN & $\mathrm{NH}_{4}-\mathrm{N}$ & $\mathrm{NO}_{3}-\mathrm{N}$ & $\mathrm{K}$ & $\mathrm{Ca}$ & $\mathrm{Mg}$ & TS & TSS & VSS & COD \\
\hline & & & & & & & $-m$ & $\mathrm{~g} \mathrm{~L}^{-1}$ & & & & & 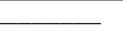 \\
\hline 1 & $8.1 \neq$ & 60.9 & 34.4 & 366 & 296 & 2.0 & 369 & 49.8 & 9.5 & 1706 & 260 & 223 & 763 \\
\hline 2 & 8.6 & 79.1 & 79.1 & 260 & 254 & 0.0 & 269 & 123 & 55.0 & 1366 & 302 & 244 & 623 \\
\hline 3 & 8.2 & 61.0 & 44.7 & 858 & 712 & 0.0 & 948 & 42.9 & 6.6 & 3355 & 285 & 250 & 1481 \\
\hline 4 & 8.0 & 85.2 & 77.7 & 587 & 577 & 0.0 & 760 & 46.4 & 12.0 & 2598 & 483 & 353 & 1174 \\
\hline 5 & 8.0 & 26.0 & 17.8 & 579 & 402 & 0.0 & 738 & 62.1 & 20.8 & 1776 & 530 & 415 & 1095 \\
\hline 6 & 8.4 & 40.1 & 38.8 & 122 & 100 & 20.0 & 339 & 25.4 & 23.6 & 4334 & 390 & 317 & 689 \\
\hline 7 & 7.9 & 65.4 & 64.3 & 371 & 255 & 0.0 & 645 & 24.2 & 252 & 3288 & 458 & 383 & 965 \\
\hline 8 & 8.5 & 61.7 & 51.9 & 468 & 332 & 0.0 & 949 & 25.3 & 12.3 & 2894 & 398 & 328 & 1013 \\
\hline 9 & 7.9 & 59.7 & 33.2 & 261 & 151 & 3.0 & 303 & 63.0 & 46.3 & 1962 & 655 & 578 & 1133 \\
\hline 10 & 8.2 & 72.9 & 68.0 & 849 & 723 & 0.0 & 834 & 47.2 & 5.9 & 3431 & 365 & 293 & 1515 \\
\hline Mean & $8.2(0.1) \S$ & $61.2(5.5)$ & $51.0(6.6)$ & $472(78)$ & $380(70)$ & $3.0(2.0)$ & $615(86)$ & $50.9(9.2)$ & $44.4(23.7)$ & $2671(302)$ & $413(39)$ & $338(33)$ & $1045(96)$ \\
\hline
\end{tabular}


and peroxide (Peters et al., 2003), and $\mathrm{K}$, $\mathrm{Ca}$, and $\mathrm{Mg}$ contents were determined by inductively coupled plasma spectrometry (Model 61E; Thermo Jarrell-Ash Corp., Franklin, MA).

The inorganic $\mathrm{P}$ content of the solid precipitate was determined in a diluted acid extraction (Vanotti et al., 2003). In this acid extraction, $5 \mathrm{~mL}$ of $1.0 \mathrm{~mol} \mathrm{~L}^{-1} \mathrm{HCl}$ was added to $100 \mathrm{mg}$ of air-dry precipitate in a test tube, vortexed for $1 \mathrm{~min}$, and allowed to sit for $1 \mathrm{~h}$. The acid extract was diluted to $75 \mathrm{~mL}$ with distilled water and analyzed for P with the automated method described previously (APHA, AWWA, and WEF, 1998).

\section{Statistical Analysis}

Analysis of variance was used to test the hypotheses that there were differences in treated effluent $\mathrm{P}$ concentration and $\mathrm{pH}$ among lagoons, nitrification pre-treatment, and $\mathrm{Ca}$ application rates (replicate $\times$ lagoon $\times$ pre-treatment $\times$ Ca rate) . The ANOVA included the effect of the following interactions: lagoon $\times$ pretreatment, pretreatment $\times$ Ca rate, and lagoon $\times$ pretreatment $\times$ Ca rate. Statistical analysis was performed using the General Linear Model procedure and linear and nonlinear regression procedures (proc REG and proc NLIN) (SAS Institute, Cary, NC).

\section{Results And Discussion}

\section{Liquid Swine Manure Characteristics}

Typically, swine farms specialize in the breeding, weaning, or finishing aspects of production, each with different feed mixture and metabolism, which affect composition of the manure. Manure undergoes further changes in its composition due to handling during the time between manure voiding by the animal and transport to the field for spreading (Barker and Zublena, 1995). Because different manure management systems conserve or loose varying amounts of nutrients, it was expected that the surface liquids from the diverse treatment lagoons in our study have variable nutrient composition (Table 2). All lagoons in our study were single-stage anaerobic lagoons, except for the liquid sampled on farm number six that was from the third lagoon in a three-stage lagoon system with the lowest $\mathrm{NH}_{4}-\mathrm{N}$ concentration. In this lagoon, the $\mathrm{NO}_{3}-\mathrm{N}$ concentration of $20 \mathrm{mg} \mathrm{L}^{-1}$ and surface greenish color (Table 1) were characteristic of an aerobic lagoon (Barker and Zublena, 1995).

A wide range of TP concentrations is usually found in surface liquid of North Carolina's anaerobic lagoons (Bicudo et al., 1999). Our dataset shows that TP ranged from $26 \mathrm{mg} \mathrm{L}^{-1}$ to $85 \mathrm{mg} \mathrm{L}^{-1}$. About 56 to $100 \%$ of TP was in soluble P form, which is the most "reactive" and critical P fraction contributing to accelerated eutrophication of surface waters (Pote and Daniel, 2000). Concentrations of TKN ranged between 122 and $858 \mathrm{mg} \mathrm{L}^{-1}$. The inorganic portion of TKN was approximately 58 to $98 \%$ in the form of $\mathrm{NH}_{4}-\mathrm{N}$. Although $\mathrm{NH}_{4}-\mathrm{N}$ concentrations levels were as high as $723 \mathrm{mg} \mathrm{L}^{-1}$ in lagoon 10, that level was below the mean $\mathrm{NH}_{4}-\mathrm{N}$ concentration of $835 \mathrm{mg} \mathrm{L}^{-1}$ observed in another study of nitrification of liquid swine manure (Vanotti et al., 2007).

Anaerobic lagoon treatment effectively degrades high-COD organic waste (Bicudo et al., 1999), such that the remaining COD in surface lagoon liquid might not be a limitation to nitrification. High COD content may limit nitrification of wastewater because nitrifying bacteria do not compete well with heterotrophic bacteria for limited oxygen and nutrients (Figueroa and Silverstein, 1992). In our study, lagoons had COD within the range of 623 to $1515 \mathrm{mg} \mathrm{COD} \mathrm{L}^{-1}$. This range of COD agrees with the initial influent CODs of 814 and $1107 \mathrm{mg} \mathrm{L}^{-1}$ reported in two previous nitrification studies of lagoon liquid with nitrifying pellets (Vanotti and Hunt, 2000; Vanotti et al., 2003).

\section{Nitrification-Alkalinity-pH Relationships}

The effect of nitrification pretreatment (PT) on $\mathrm{pH}$ of the 10 studied lagoon was statistically significant (Table 3 ). The effect of nitrification on alkalinity is shown in Table 4 for the 10 swine lagoon liquids with and without a nitrification pretreatment. Changes in lagoon liquid characteristics $\left(\mathrm{NH}_{4}-\mathrm{N}, \mathrm{NO}_{3}-\mathrm{N}\right.$, and alkalinity) after nitrification indicated that alkalinity was significantly consumed in all cases, producing a $\mathrm{NO}_{3}-\mathrm{N}$-rich effluent (mean $\mathrm{NO}_{3}-\mathrm{N}=262 \pm 40 \mathrm{mg} \mathrm{L}^{-1}$ ). Without exception, the natural carbonate alkalinity of the lagoon liquid was significantly reduced in the process of biological $\mathrm{NH}_{4}^{+}$oxidation during the nitrification pretreatment (average alkalinity changed from $2279 \pm 300 \mathrm{mg} \mathrm{L}^{-1}$ to $91 \pm 14 \mathrm{mg} \mathrm{L}^{-1}$; Table 4).

Even though a $\mathrm{pH} \geq 9.0$ is needed to optimize precipitation of phosphate using Ca-based compounds (Loehr et al., 1976; Tomson and Vignona, 1984; House, 1999), the $\mathrm{pH}$ of the liquid was initially lowered with the acid produced by nitrifying bacteria. In this way, the resulting nitrified liquid was low in $\mathrm{NH}_{4}^{+}$and bicarbonate buffers, and the total amount of alkali needed to increase the $\mathrm{pH}$ above 9.0 was significantly reduced. According to the ANOVA tests, the effects of $\mathrm{Ca}$ application rate $(\mathrm{CaR})$ and the interaction $\mathrm{PT} \times \mathrm{CaR}$ on $\mathrm{pH}$ were highly significant (Table 3). Results of the effect of $\mathrm{Ca}$ application rate on $\mathrm{pH}$ of the 10 lagoon liquids with and without nitrification treatment are presented in Table 5. For example, on lagoon 4, a Ca rate of $6 \mathrm{mmol} \mathrm{L}^{-1}$ was needed to increase the $\mathrm{pH}$ of the nitrified liquid from 6.2 to 9.0. In contrast, an addition of twice the $\mathrm{Ca}(\mathrm{OH})_{2}\left(12 \mathrm{mmol} \mathrm{Ca} \mathrm{^{-1 } )}\right.$ to the same lagoon liquid without nitrification increased the $\mathrm{pH}$ only 0.3 units and was not sufficient to reach the desired target $\mathrm{pH}$ above 9.0 to enhance $\mathrm{P}$ precipitation (Table 5).

The significant effect of $\mathrm{Ca}$ application rates and lagoon liquid pretreatment on effluent $\mathrm{pH}$ is shown in Fig. 2. On average, the rate of change of effluent $\mathrm{pH}\left(0.42 \mathrm{pH}\right.$ units $\left./ \mathrm{mmol} \mathrm{Ca} \mathrm{L}^{-1}\right)$ for the prenitrified lagoon liquid was significantly different $(P<0.0001)$ and higher than the rate for the control without nitrification $\left(0.05 \mathrm{pH}\right.$ units $\left./ \mathrm{mmol} \mathrm{CaL}^{-1}\right)$. These results illustrate that precipitation of phosphate using lime in untreated livestock effluents is inefficient because of the high natural buffer capacity of these effluents, which prevents rapid changes in $\mathrm{pH}$.

An additional advantage of prenitrifying the lagoon liquid is that it minimizes $\mathrm{N}$ losses by $\mathrm{NH}_{3}$ volatilization at the high $\mathrm{pH}(>9.0)$ needed to precipitate P using Ca compounds (Eq. [4]). Total inorganic $\mathrm{N}$ in the control of lagoon one decreased linearly $\left(R^{2}=0.99\right.$; Fig. 3$)$. The inorganic $\mathrm{N}$ loss with respect to the initial total inorganic $\mathrm{N}$ in the control was as high as 
Table 3. Analysis of variance for the effect of nitrification pretreatment and hydrated lime application rate on the treated effluent $\mathrm{pH}$ and total phosphorus concentration of 10 swine lagoons in North Carolina.

\begin{tabular}{|c|c|c|c|c|c|}
\hline & \multirow[b]{3}{*}{ df } & \multicolumn{4}{|c|}{ Effluent characteristics } \\
\hline & & \multicolumn{2}{|c|}{$\mathrm{pH}$} & \multicolumn{2}{|c|}{ Total P concentration } \\
\hline & & Mean square values & Significance probability & Mean square values & Significance probability \\
\hline Replicate $(R)$ & 1 & 0.005 & 0.7522 & 34 & 0.1155 \\
\hline Lagoon (L) & 9 & 5.9 & $<0.0001$ & 5017 & $<0.0001$ \\
\hline Pretreatment $(\mathrm{PT}) \dagger$ & 1 & 74.5 & $<0.0001$ & 39,988 & $<0.0001$ \\
\hline $\mathrm{L} \times \mathrm{PT}$ & 9 & 2.2 & $<0.0001$ & 1280 & $<0.0001$ \\
\hline Ca rate $(\mathrm{CaR}) \neq$ & 6 & 41.3 & $<0.0001$ & 10,144 & $<0.0001$ \\
\hline $\mathrm{PT} \times \mathrm{CaR}$ & 6 & 28.0 & $<0.0001$ & 1876 & $<0.0001$ \\
\hline $\mathrm{L} \times \mathrm{PT} \times \mathrm{CaR}$ & 50 & 0.24 & $<0.0001$ & 116 & $<0.0001$ \\
\hline
\end{tabular}

† With or without nitrification pretreatment.

‡ Calcium applied as $\mathrm{Ca}(\mathrm{OH})_{2}$; rates $=0,2,4,6,8,10$, and $12 \mathrm{mmol} \mathrm{L}^{-1}$ of lagoon liquid (Table 4).

Table 4. Swine lagoon liquid characteristics before lime application with and without prenitrification treatment. Data are means of duplicate experiments.

\begin{tabular}{|c|c|c|c|c|c|}
\hline \multirow[b]{2}{*}{ Lagoon no. } & \multirow{2}{*}{$\begin{array}{l}\text { Nitrification } \\
\text { pretreatment }\end{array}$} & \multicolumn{4}{|c|}{ Parameters } \\
\hline & & $\mathrm{NH}_{4}-\mathrm{N}$ & $\mathrm{NO}_{3}-\mathrm{N}$ & Alkalinity† & $\mathrm{pH}$ \\
\hline & & & $-\mathrm{mg} \mathrm{L}^{-1}$ & & \\
\hline \multirow[t]{2}{*}{$1 \neq$} & yes & 79 & 291 & 63 & 6.2 \\
\hline & no & 296 & 2 & 2292 & 8.1 \\
\hline \multirow[t]{2}{*}{2} & yes & 41 & 206 & 103 & 6.0 \\
\hline & no & 254 & 0 & 1427 & 8.6 \\
\hline \multirow[t]{2}{*}{3} & yes & 15 & 308 & 130 & 6.4 \\
\hline & no & 712 & 0 & 3618 & 8.2 \\
\hline \multirow[t]{2}{*}{4} & yes & 68 & 523 & 78 & 6.2 \\
\hline & no & 577 & 0 & 3062 & 8.0 \\
\hline \multirow[t]{2}{*}{5} & yes & 76 & 293 & 156 & 6.4 \\
\hline & no & 402 & 0 & 2858 & 8.0 \\
\hline \multirow[t]{2}{*}{6} & yes & 0 & 100 & 129 & 7.5 \\
\hline & no & 100 & 20 & 953 & 8.4 \\
\hline \multirow[t]{2}{*}{7} & yes & 42 & 218 & 52 & 6.6 \\
\hline & no & 255 & 0 & 1854 & 7.9 \\
\hline \multirow[t]{2}{*}{8} & yes & 17 & 313 & 52 & 6.1 \\
\hline & no & 332 & 0 & 2498 & 8.5 \\
\hline \multirow[t]{2}{*}{9} & yes & 3 & 132 & 20 & 6.3 \\
\hline & no & 151 & 3 & 1004 & 7.9 \\
\hline \multirow[t]{2}{*}{10} & yes & 77 & 236 & 129 & 6.3 \\
\hline & no & 723 & 0 & 3219 & 8.2 \\
\hline \multirow[t]{2}{*}{ Mean } & yes & $42(10) \S$ & $262(37)$ & $91(14)$ & $6.4(0.1)$ \\
\hline & no & $380(70)$ & $2.5(2.0)$ & $2279(298)$ & $8.2(0.1)$ \\
\hline
\end{tabular}

† Alkalinity as $\mathrm{mg} \mathrm{L}^{-1}$ of $\mathrm{CaCO}_{3}$.

\# Within the same lagoon, mean differences between with (yes) and without (no) nitrification pretreatment were significant for $\mathrm{NH}_{4}-\mathrm{N}$, $\mathrm{NO}_{3}-\mathrm{N}$, alkalinity, and $\mathrm{pH}$ ( $t$ test, $n=2 ; P<0.05$ ).

$\S$ Numbers in parentheses are SEM.

$27 \%$ at $\mathrm{pH} 9.0$ and $70 \%$ at $\mathrm{pH} 11$. This inorganic $\mathrm{N}$ loss was most likely due to $\mathrm{NH}_{3}$ volatilization at a rate of approximately $66 \mathrm{mg}$ inorganic $\mathrm{N}$ per unit of $\mathrm{pH}$. Instead, inorganic $\mathrm{N}$ losses were not significant within the nitrified lagoon liquid because total inorganic $\mathrm{N}$ remained constant with increasing $\mathrm{pH}$ after alkali addition $\left(R^{2}=0.068\right.$; Fig. 3$)$.

\section{Phosphorus Removal from Swine Lagoon Liquid}

The effects of nitrification pretreatment, $\mathrm{Ca}$ application rate, and PT $\times \mathrm{CaR}$ interaction on TP concentration of the 10 treated lagoon effluents were statistically significant (Table 3). The prenitrification step greatly enhanced the $\mathrm{P}$ removal with
Table 5. Effect of prenitrification treatment and hydrated lime application rate on the treated effluent $\mathrm{pH}$ of 10 swine lagoons in North Carolina.

\begin{tabular}{|c|c|c|c|c|c|c|c|c|}
\hline \multirow{2}{*}{$\begin{array}{l}\text { Lagoon } \\
\text { no. }\end{array}$} & \multirow{2}{*}{$\begin{array}{c}\text { Nitrification } \\
\text { pretreatment }\end{array}$} & \multicolumn{7}{|c|}{ Calcium application rate $\left(\mathrm{mmol} \mathrm{L}^{-1}\right) \dagger$} \\
\hline & & 0 & 2 & 4 & 6 & 8 & 10 & 12 \\
\hline & & & & $-\mathrm{E}$ & fluent & $\mathrm{OH}-$ & & \\
\hline \multirow[t]{2}{*}{1} & yes & $6.2 \neq$ & 7.9 & 8.8 & 9.5 & 10.1 & 10.6 & 11.2 \\
\hline & no & 8.1 & 8.1 & $-\S$ & - & - & 8.3 & - \\
\hline \multirow[t]{2}{*}{2} & yes & 6.0 & 6.0 & 6.8 & 7.8 & 10.7 & 10.8 & 11.5 \\
\hline & no & 8.6 & 7.6 & 7.8 & 7.9 & 8.2 & 8.3 & 8.5 \\
\hline \multirow[t]{2}{*}{3} & yes & 6.4 & 7.5 & 8.8 & 9.6 & 10.2 & 10.4 & 11.5 \\
\hline & no & 8.2 & 8.3 & 8.4 & 8.5 & 8.5 & 8.6 & 8.5 \\
\hline \multirow[t]{2}{*}{4} & yes & 6.2 & 7.4 & 8.3 & 9.0 & 9.4 & 10.1 & 10.8 \\
\hline & no & 8.0 & 8.1 & 8.1 & 8.2 & 8.3 & 8.3 & 8.3 \\
\hline \multirow[t]{2}{*}{5} & yes & 6.4 & 8.3 & 9.1 & 9.8 & 10.7 & 11.3 & 11.6 \\
\hline & no & 8.0 & 8.2 & 8.3 & 8.4 & 8.6 & 8.6 & 8.6 \\
\hline \multirow[t]{2}{*}{6} & yes & 7.5 & 10.1 & 11.3 & 11.6 & 11.8 & 11.9 & 12.0 \\
\hline & no & 8.4 & 8.6 & 8.7 & 8.9 & 9.0 & 9.2 & 9.3 \\
\hline \multirow[t]{2}{*}{7} & yes & 6.6 & 7.7 & 9.1 & 9.9 & 10.8 & 11.3 & 11.5 \\
\hline & no & 7.9 & 8.2 & 8.2 & 8.3 & 8.4 & 8.5 & 8.5 \\
\hline \multirow[t]{2}{*}{8} & yes & 6.1 & 7.8 & 8.4 & 10.2 & 10.7 & 11.5 & 11.8 \\
\hline & no & 8.5 & 8.6 & 8.5 & 8.5 & 8.7 & 8.7 & 8.8 \\
\hline \multirow[t]{2}{*}{9} & yes & 6.3 & 9.2 & 10.4 & 11.1 & 11.5 & 11.7 & 11.9 \\
\hline & no & 7.9 & 8.1 & 8.3 & 8.4 & 8.6 & 8.7 & 8.6 \\
\hline \multirow[t]{2}{*}{10} & yes & 6.3 & 7.7 & 9.1 & 9.8 & 11.0 & 11.5 & 11.7 \\
\hline & no & 8.2 & 8.3 & 8.3 & 8.4 & 8.5 & 8.5 & 8.6 \\
\hline
\end{tabular}

† Calcium applied as $\mathrm{Ca}(\mathrm{OH})_{2} ; 1 \mathrm{mmol}=74.09 \mathrm{mg} \mathrm{Ca}(\mathrm{OH})_{2}$.

₹ Data are means of two replicate experiments. LSD $=0.64$ applies for comparison between any two means at the 0.05 probability level.

$\S$ Not determined.

$\mathrm{Ca}(\mathrm{OH})_{2}$ application in all 10 lagoons (Table 6). In nitrified and non-nitrified liquids, the $\mathrm{P}$ removal started with $\mathrm{Ca}$ application of $2 \mathrm{mmol} \mathrm{L}^{-1}$. For instance, on lagoon 4 , effluent TP concentration decreased $22 \%\left(66.3 \mathrm{mg} \mathrm{L}^{-1}\right)$ in the nitrified liquid with as little as $2 \mathrm{mmol} \mathrm{Ca} \mathrm{\textrm {L } ^ { - 1 }}$ with respect to an initial TP concentration of $85.2 \mathrm{mg} \mathrm{L}^{-1}$. However, only $1 \%\left(84.4 \mathrm{mg} \mathrm{L}^{-1}\right)$ reduction in TP concentration in the non-nitrified liquid was attained at the same Ca rate of $2 \mathrm{mmol} \mathrm{L}^{-1}$. At a Ca rate of $6 \mathrm{mmol} \mathrm{L}^{-1}$ in the same lagoon liquid, the $\mathrm{P}$ concentration reduction was $89 \%\left(9.6 \mathrm{mg} \mathrm{L}^{-1}\right)$ in the nitrified versus a reduction of only $14 \%$ (73.0 $\mathrm{mg} \mathrm{L}^{-1}$ ) in the non-nitrified liquid.

The significant effect of lagoon pretreatment and Ca application rates on reducing effluent TP is shown in Fig. 4. At increasing $\mathrm{Ca}$ application rates, the reduction in effluent TP of lagoon 


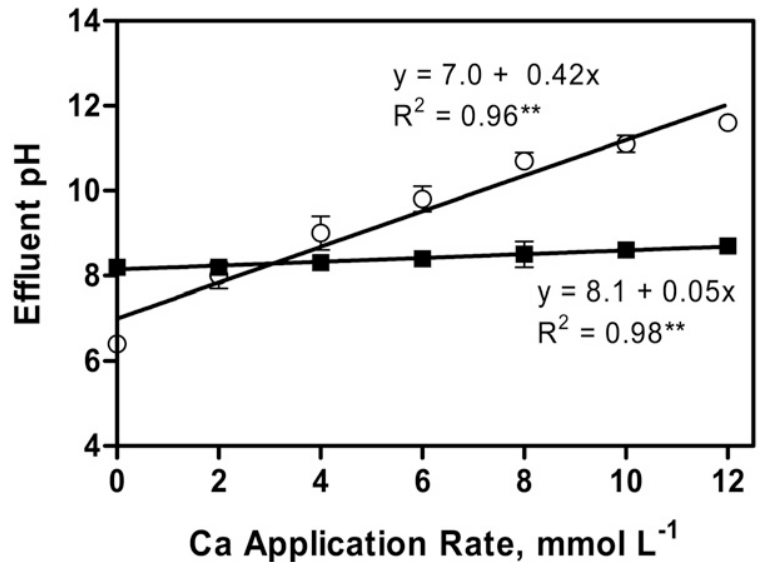

Fig. 2. Effect of $\mathrm{Ca}$ application rate on effluent $\mathrm{pH}$ from lagoon liquid pretreated with nitrification and without nitrification (control). Data points indicate means of 10 lagoons $(n=10)$, and error bars represent $1 \mathrm{SE}$.

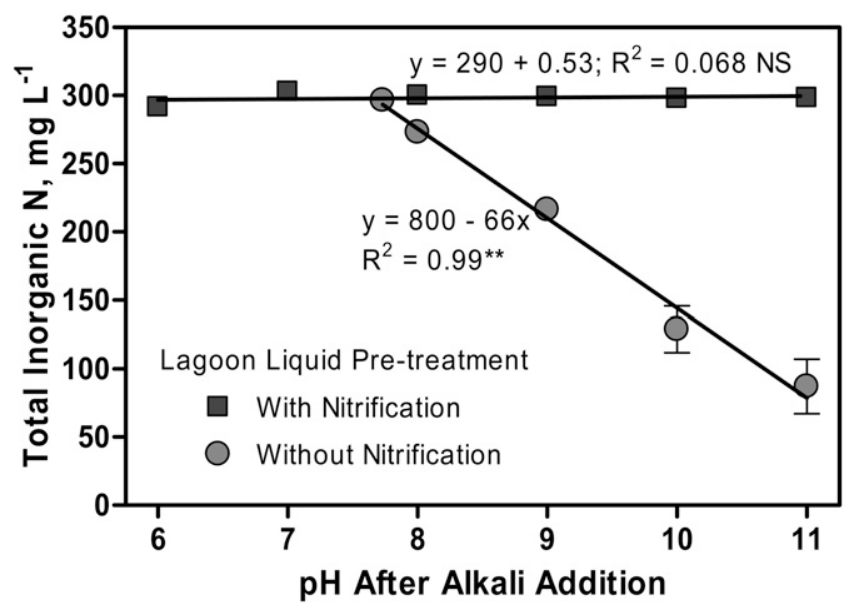

Fig. 3. Effect of raising $\mathrm{pH}$ with $\mathrm{NaOH}$ on total inorganic $\mathrm{N}$ concentration in lagoon liquid pretreated with nitrification and without nitrification (control). Data were obtained using liquid from lagoon 1 only, and error bars represent $1 \mathrm{SE}(n=2)$. Total inorganic $\mathrm{N}$ is the sum of $\mathrm{NH}_{4}-\mathrm{N}$ plus $\mathrm{NO}_{3}-\mathrm{N}$.

liquid without nitrification decreased linearly. With prenitrified lagoon liquid, the effluent TP concentrations decreased exponentially at increasing $\mathrm{Ca}$ application rates. On average, prenitrified samples treated with hydrated lime had significantly lower TP concentrations than the non-nitrified control. These results confirm that precipitation of phosphate using lime in untreated livestock effluents is very inefficient because of the inherent high natural buffer capacity of these effluents, which prevents rapid changes in $\mathrm{pH}$ and $\mathrm{TP}$ concentrations.

Total P removal efficiencies with the non-nitrified (control) treatment never exceeded $50 \%$, even at the highest Ca rate of $12 \mathrm{mmol} \mathrm{L}^{-1}$ used in this study (Fig. 5). Instead, high TP removal efficiencies of $>90 \%$ were achieved at Ca rates between 8 and $10 \mathrm{mmol} \mathrm{L}^{-1}\left(0.3\right.$ and $\left.0.4 \mathrm{~g} \mathrm{Ca} \mathrm{L}^{-1}\right)$ in the nitrified samples. Similar high $\mathrm{P}$ removal efficiencies (70-95\%) were obtained by Parent et al. (2007) when a Mg smelting product was added to liquid swine manure collected from concrete pits at a rate between 0.5 and $3 \mathrm{~g} \mathrm{Mg} \mathrm{L}^{-1}$. This was achieved without nitrifi-
Table 6. Removal of phosphorus from effluents of 10 North Carolina swine lagoons using hydrated lime with and without a nitrification pretreatment.

\begin{tabular}{|c|c|c|c|c|c|c|c|c|}
\hline \multirow{3}{*}{$\begin{array}{l}\text { Lagoon } \\
\text { no. }\end{array}$} & \multirow{3}{*}{$\begin{array}{c}\text { Nitrification } \\
\text { pretreatment }\end{array}$} & \multicolumn{7}{|c|}{ Effluent total $\mathrm{P}\left(\mathrm{mg} \mathrm{L}^{-1}\right)$} \\
\hline & & \multicolumn{7}{|c|}{ Calcium application rate $\left(\mathrm{mmol} \mathrm{L}^{-1}\right) \dagger$} \\
\hline & & 0 & 2 & 4 & 6 & 8 & 10 & 12 \\
\hline \multirow[t]{2}{*}{1} & yes & $60.9 \neq$ & 45.5 & 27.0 & 13.9 & 4.9 & 0.0 & 0.0 \\
\hline & no & 60.9 & 52.1 & $-\S$ & - & - & 47.1 & - \\
\hline \multirow[t]{2}{*}{2} & yes & 79.1 & 76.6 & 46.3 & 13.2 & 5.0 & 2.0 & 0.0 \\
\hline & no & 79.1 & 70.3 & 68.0 & 45.3 & 39.1 & 35.1 & 17.3 \\
\hline \multirow[t]{2}{*}{3} & yes & 61.0 & 39.3 & 14.8 & 12.4 & 0.0 & 0.1 & 0.2 \\
\hline & no & 61.0 & 60.3 & 59.2 & 56.6 & 51.3 & 46.4 & 50.8 \\
\hline \multirow[t]{2}{*}{4} & yes & 85.2 & 66.3 & 33.4 & 9.6 & 0.9 & 0.0 & 0.0 \\
\hline & no & 85.2 & 84.4 & 77.3 & 73.0 & 74.3 & 68.2 & 68.6 \\
\hline \multirow[t]{2}{*}{5} & yes & 26.0 & 10.2 & 3.7 & 1.9 & 0.0 & 0.0 & 0.0 \\
\hline & no & 26.0 & 18.9 & 15.3 & 11.7 & 6.1 & 4.3 & 2.9 \\
\hline \multirow[t]{2}{*}{6} & yes & 40.1 & 12.6 & 12.4 & 5.5 & 2.5 & 0.0 & 0.1 \\
\hline & no & 40.1 & 38.5 & 24.7 & 16.8 & 11.4 & 10.7 & 10.0 \\
\hline \multirow[t]{2}{*}{7} & yes & 65.4 & 50.9 & 24.4 & 8.1 & 7.5 & 7.2 & 0.0 \\
\hline & no & 65.4 & 60.6 & 59.5 & 54.9 & 52.5 & 53.1 & 50.0 \\
\hline \multirow[t]{2}{*}{8} & yes & 61.7 & 48.3 & 27.8 & 16.8 & 9.3 & 8.6 & 5.0 \\
\hline & no & 61.7 & 59.1 & 55.4 & 47.5 & 49.1 & 43.5 & 43.7 \\
\hline \multirow[t]{2}{*}{9} & yes & 59.7 & 34.7 & 21.9 & 17.0 & 4.1 & 1.4 & 0.0 \\
\hline & no & 59.7 & 43.8 & 33.3 & 25.4 & 19.6 & 19.2 & 20.2 \\
\hline \multirow[t]{2}{*}{10} & yes & 72.9 & 51.6 & 32.8 & 22.6 & 13.4 & 7.4 & 6.0 \\
\hline & no & 72.9 & 67.0 & 69.3 & 68.0 & 59.1 & 60.9 & 60.0 \\
\hline
\end{tabular}

† Calcium applied as $\mathrm{Ca}(\mathrm{OH})_{2} ; 1 \mathrm{mmol}=74.09 \mathrm{mg} \mathrm{Ca}(\mathrm{OH})_{2}$.

\# Data are means of two replicate experiments. LSD $=8.06$ applies for comparison between any two means at the 0.05 probability level.

$\S$ Not determined.

cation and a natural settling period of $\geq 8$. Instead, our process did not include natural settling; it treated surface lagoon liquid (only), producing low-P effluents and a concentrated $\mathrm{P}$ precipitate with minimal chemical addition $\left(<0.4 \mathrm{~g} \mathrm{Ca} \mathrm{L}^{-1}\right)$.

\section{Implications of $\mathrm{NH}_{4}{ }^{+}$and Carbonate Buffer Consumption}

The $\mathrm{pH}$ and alkalinity are important parameters that should be considered for optimum biological $\mathrm{N}$ treatment. Autotrophic microbial biomass growth may cease due to insufficient wastewater alkalinity. Nitrifying bacteria rely on alkalinity to transform $\mathrm{NH}_{4}^{+}$into $\mathrm{NO}_{3}^{-}$(Eq. [5] and Eq. [6]) because carbonate and bicarbonate are needed for microbial metabolism and neutralizing the acid $\mathrm{pH}$ during the production of $\mathrm{NO}_{3}^{-}$(Grady et al., 1999; Vanotti and Hunt, 2000). As a result of the nitrification process, there is, in theory, a release of protons at a rate of 2 moles of $\mathrm{H}^{+}$for each mole of $\mathrm{NH}_{4}^{+}$oxidized (Eq. [5]). The nitrification pretreatment was considered complete for the purposes of $\mathrm{P}$ removal and terminated in the experiments when more than $90 \%$ of the natural alkalinity of the lagoon liquid was exhausted in the process of biological $\mathrm{NH}_{4}^{+}$oxidation to $\mathrm{NO}_{3}^{-}$.

The natural alkalinity consumption estimated for oxidation of $\mathrm{NH}_{4}{ }^{+}$is $7.14 \mathrm{mg} \mathrm{CaCO}_{3}$ per $\mathrm{mg} \mathrm{NH}_{4}-\mathrm{N}$ oxidized (Sherrard, 1976). This relationship for the 10 swine lagoons is shown in Fig. 6. Although seven lagoons were close to the theoretical ratio, three lagoons significantly departed from the 7.14 line. These three lagoons contained the highest COD contents (lagoons 3, 4, and 10 with 1481, 1174, and $1515 \mathrm{mg} \mathrm{COD} \mathrm{L}^{-1}$, respectively; Table 2). High COD concentrations can contrib- 


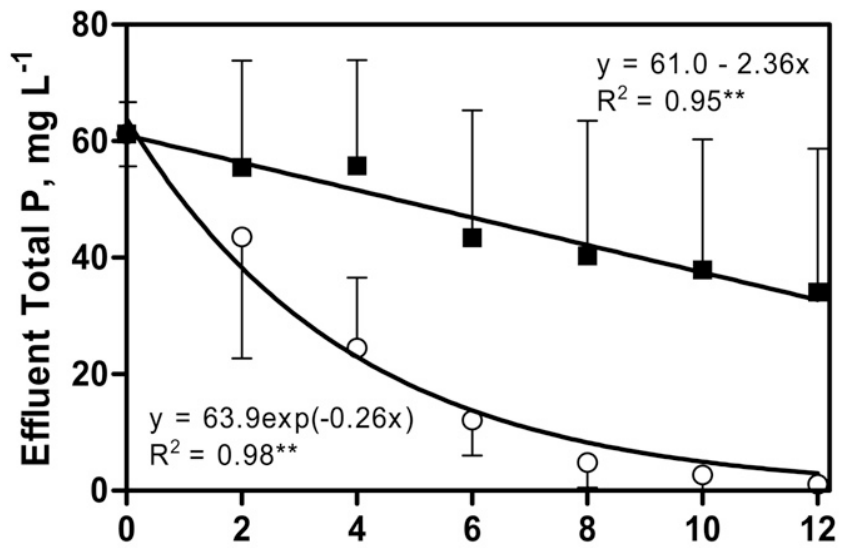

Ca Application Rate. $\mathrm{mmol} \mathrm{L}^{-1}$

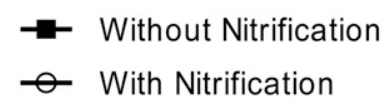

Fig. 4. Effect of $\mathrm{Ca}$ application rate on effluent total $P$ from lagoon liquid pretreated with nitrification and without nitrification (control). Data points indicate means of 10 lagoons $(n=10)$, and error bars represent $1 \mathrm{SE}$.

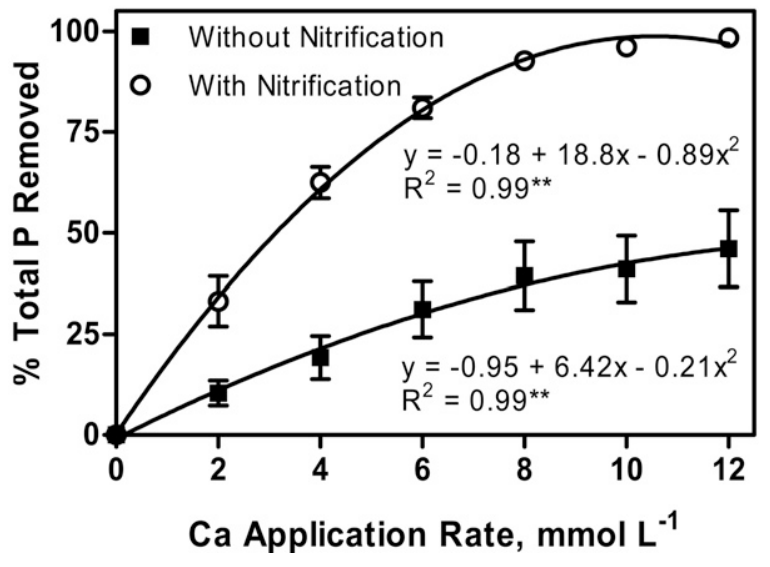

Fig. 5. Phosphorus removal enhancement from lagoon wastewater using hydrated lime and nitrification pretreatment. Percent $\mathbf{P}$ removed is the $P$ removed from the lagoon liquid relative to initial lagoon liquid total $P$ concentrations (Table 6). Bars indicate means, and error bars represent $1 \mathrm{SE}$ ( $n=10$ lagoons).

ute to a post-aeration reaction where endogenous manure $\mathrm{C}$ is used to reduce $\mathrm{NO}_{3}^{-}$concentrations by bacterial activity (Randall et al., 1992). This additional denitrification reaction changes the theoretical 7.14 ratio that considers only nitrification because there is a production of approximately 3.57 mg-CaCO ${ }_{3}$ per mg $\mathrm{N}$ converted to $\mathrm{N}_{2}$. This second reaction releases approximately 2 moles of $\mathrm{H}^{+}$per mole of $\mathrm{NH}_{4}^{+}$oxidized and consumes approximately 1 mole of $\mathrm{H}^{+}$per mole of $\mathrm{NO}_{3}^{-}$reduced (Tchobanoglous and Burton, 1991). For this reason, we calculated the alkalinity consumption due to nitrification and possible denitrification based on the $\mathrm{NH}_{4}-\mathrm{N}$ and $\mathrm{NO}_{3}-\mathrm{N}$ concentrations before and after the $\mathrm{N}$ removal step (Fig. 7). The result of this calculation (Fig. 7) shows that the measured alkalinity consumption in the 10 experiments was

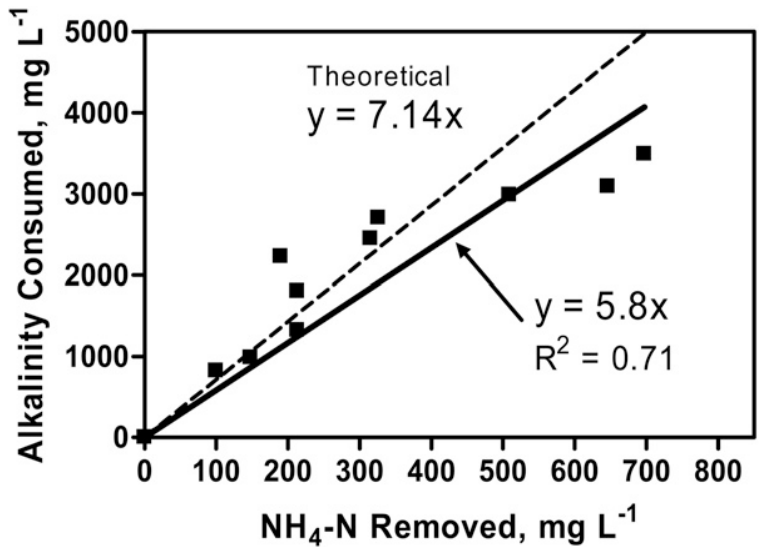

Fig. 6. Effect of prenitrification treatment on simultaneous consumption of carbonate alkalinity and ammonium in lagoon liquid. The slope of the line $y=7.14 x$ represents the theoretical consumption of $7.14 \mathrm{mg}-\mathrm{CaCO}_{3}$ per $\mathrm{mg} \mathrm{NH}_{4}-\mathrm{N}$ oxidized for complete oxidation of $\mathrm{NH}_{4}-\mathrm{N} \mathrm{L}^{-1}$ in the lagoon liquid. Each data point is the mean of two nitrification treatments per lagoon liquid $(n=2)$.

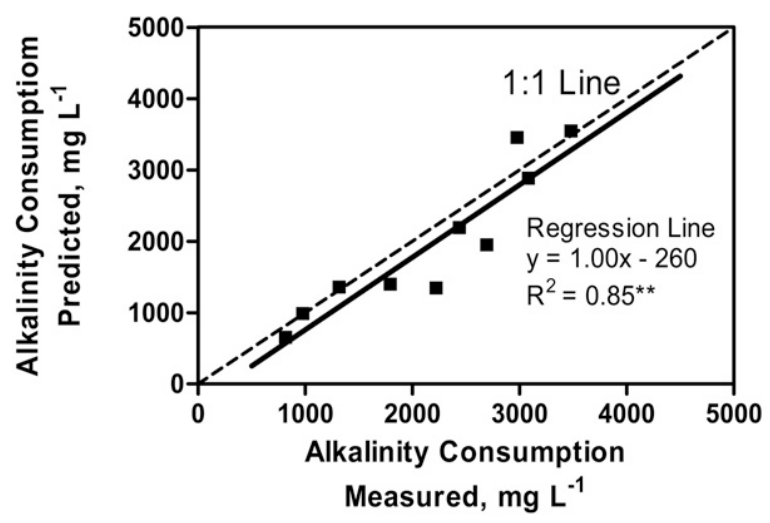

Fig. 7. Relationship between measured alkalinity consumption and predictedalkalinity consumption during prenitrification of lagoon liquids. The predicted alkalinity consumption was estimated considering an alkalinity consumption of approximately 3.57 mg-CaCO ${ }_{3}$ per $\mathrm{mg} \mathrm{N}$ converted to $\mathrm{N}_{2}$ (i.e., release of 2 moles of $\mathrm{H}^{+}$ per mole of $\mathrm{NH}_{4}^{+}$oxidized and consumption of 1 mole of $\mathrm{H}^{+}$per mole of $\mathrm{NO}_{3}{ }^{-}$reduced).

well explained by the changes in alkalinity due to $\mathrm{NH}_{4}^{+}$oxidation (nitrification) and $\mathrm{NO}_{3}{ }^{-}$reduction (denitrification).

\section{Effect of $\mathrm{NH}_{4}^{+}$and Carbonate Buffer on Process $\mathrm{pH}$}

The effect of natural buffer removal on the amount of alkali needed to optimize the process $\mathrm{pH}$ for $\mathrm{P}$ removal was evaluated using liquid from lagoons 1 and 2 (Fig. 8 and Table 7). The evaluation consisted of comparing the consumption of alkali $(\mathrm{NaOH})$ to reach pH 10 in three situations: (i) the original liquid swine manure with its natural buffers intact (control), (ii) lagoon liquid with carbonate alkalinity removed by chemical acidification, and (iii) lagoon liquid with $\mathrm{NH}_{4}^{+}$and carbonate alkalinity removed by biological nitrification. Results of these tests showed that the lagoon liquid with $\mathrm{NH}_{4}^{+}$and alkalinity removed by nitrification had a significantly lower alkali requirement to elevate $\mathrm{pH}$ than the control or the acidification pretreatment (Table 7). Therefore, the use of acidification alone to reduce the carbonate buffer without $\mathrm{NH}_{4}^{+}$removal is not effective to reach the optimum 

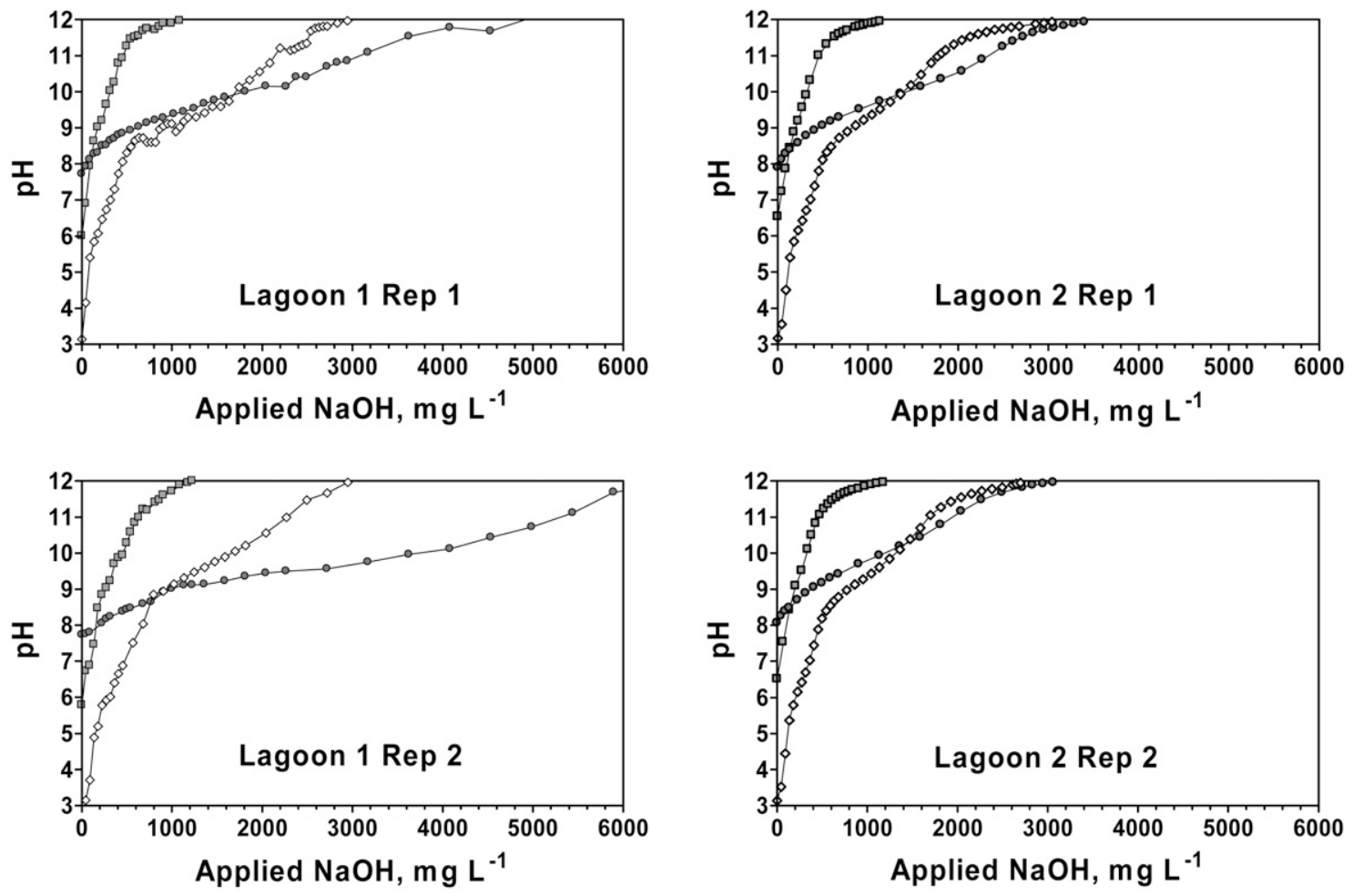

\section{Lagoon Liquid Pre-treatment}

$-\circ$ Untreated

$\neg$ Acidified (Only carbonate removed)

$\rightarrow-$ Nitrification (Ammonium and carbonate removed)

Fig. 8. Effect of alkali addition on $\mathrm{pH}$ of swine lagoon liquid that received separate treatments to remove carbonate alkalinity and prenitrification versus untreated lagoon liquid (control).

alkaline $\mathrm{pH}(>9.0)$ for $\mathrm{P}$ removal. This test confirms that the optimum $\mathrm{pH}$ process for $\mathrm{P}$ precipitation can be attained with the addition of small amounts of alkali to lagoon liquid that has undergone a biological nitrification pretreatment.

\section{Phosphorus Concentration}

Higher inorganic P concentrations were obtained in the precipitates of the new process than in precipitates of the control (Fig. 9). For instance, at the same selected $\mathrm{Ca}$ application rate of $10 \mathrm{mmol} \mathrm{L}^{-1}$, the average $\mathrm{P}_{2} \mathrm{O}_{5}$ concentration was $11.4 \pm 5.3 \%$ for precipitates obtained with the prenitrification step and only 4.0 $\pm 3.1 \%$ for the control samples (without nitrification). Inorganic

Table 7. Amount of alkali consumed to raise the initial $\mathrm{pH}$ of lagoon liquid to $\mathrm{pH} 10$.

\begin{tabular}{lcc}
\hline Lagoon liquid pretreatment & Initial pH & Applied $\mathrm{NaOH}$ \\
\hline & & $\mathrm{mg} \mathrm{L}^{-1}$ \\
Untreated & 7.86 & $1933 \mathrm{a} \dagger$ \\
Acidified & 3.03 & $1526 \mathrm{a}$ \\
Nitrification & 6.21 & $342 \mathrm{~b}$ \\
LSD & & 991 \\
\hline
\end{tabular}

† Data are means of two lagoons (lagoons 1 and 2) and two replicates per lagoon liquid pretreatment $(n=12)$. Data were obtained from Fig. 8. Means followed by the same letter are not significantly different according to LSD (0.05).
P concentration of phosphate rock from US mines (27.5-37.9\% $\mathrm{P}_{2} \mathrm{O}_{5}$; USDA-TVA, 1964) is higher than the highest $\mathrm{P}$ concentration of the recovered phosphate in this study $\left(23.0 \% \mathrm{P}_{2} \mathrm{O}_{5}\right.$ on lagoon 2; Fig. 9). Nevertheless, recovered manure $\mathrm{P}$ has the

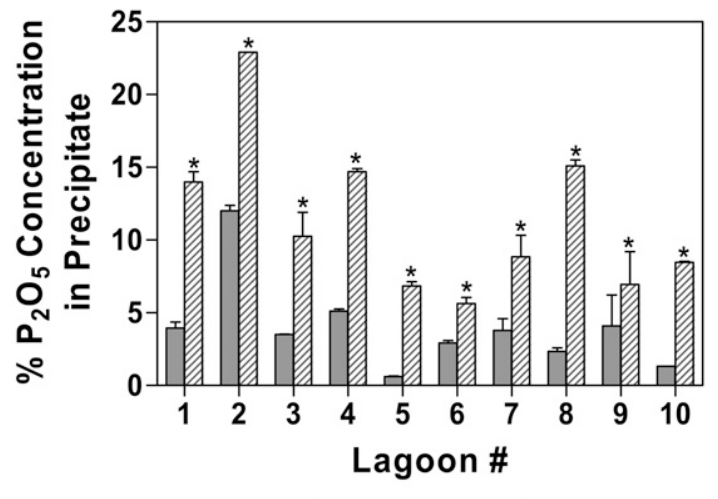

Without Nitrification

Fig. 9. Concentration of $\mathrm{P}_{2} \mathrm{O}_{5}$ in the precipitate after removal of $P$ from the liquid of 10 North Carolina swine lagoons with and without a

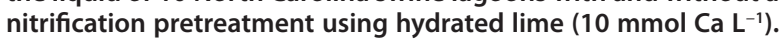
Bars indicate mean of duplicate experiments, and error bars represent 1 SD. Within the same lagoon, asterisk indicates that means with and without nitrification pretreatment were significantly different ( $t$ test, $n=2 ; P<0.05$ ). 
potential to be used as $\mathrm{P}$ fertilizer without the acid treatment used with the phosphate rock, and approximately $99 \%$ is water- or citrate soluble as determined in a previous greenhouse study (Bauer et al., 2007). The aspect of phosphate recovery and reuse is becoming important because, unlike $\mathrm{N}$, world $\mathrm{P}$ reserves are limited (Smil, 2000). Therefore, this new technology that recovers phosphate in concentrated form from liquid livestock effluents is not only useful for solving distribution problems of excess $P$ in soils associated with manure application, but it allows this nutrient to be transported off the farm in concentrated form and recycled as a value-added plant fertilizer.

\section{Conclusions}

Anaerobic lagoons are widely used to treat and store liquid manure from confined swine production facilities in North Carolina. Environmental and health concerns with the lagoonspray field method of liquid manure treatment include $\mathrm{NH}_{3}$ emissions (Aneja et al., 2000), odors (Loughrin et al., 2006; Schiffman et al., 2001), pathogens (Sobsey et al., 2001), and water-quality deterioration (Mallin, 2000). Thus, there is an interest in developing alternative swine manure treatment methods that can address these environmental problems.

A wastewater treatment process that has been previously evaluated to replace anaerobic swine lagoons to remove P from livestock effluents was used to treat swine lagoon liquid before land application. This treatment process consists of the reduction of natural buffers in manure, bicarbonate, and $\mathrm{NH}_{4}^{+}$, with biological nitrification and subsequent selective precipitation of $\mathrm{P}$ using $\mathrm{Ca}(\mathrm{OH})_{2}$. With this process, $\mathrm{P}$ was efficiently removed from lagoon liquid of 10 diverse North Carolina swine production farms. Nitrification pretreatment significantly reduced the amount of $\mathrm{Ca}(\mathrm{OH})_{2}$ needed for optimum $\mathrm{P}$ precipitation and removal while preventing $\mathrm{N}$ losses via $\mathrm{NH}_{3}$ volatilization. The two final products of this wastewater treatment process were a liquid effluent for on-farm use and a solid calcium phosphate material.

Although the treatment process is able to remove $>90 \%$ of the initial TP, elimination of $\mathrm{P}$ in the treated lagoon effluent might not be necessary because all crops need some P for growth. Our study showed that the P removal efficiency can be adjusted by controlling hydrated lime application rates. Consequently, the $\mathrm{P}$ concentration of the effluent can be reduced to match crop requirements. On the other hand, $\mathrm{P}$ can be effectively reduced to very low concentrations in the treated effluent to diminish problems of excess $\mathrm{P}$ accumulation in waste-amended soils. The $\mathrm{P}$ recovery aspect of this process is an attractive approach because of the increasing global cost of mineral fertilizers and declining world $\mathrm{P}$ reserves. The final product is a material rich in Ca phosphate that could be exported from the farm in concentrated form to be reused as fertilizer.

\section{Acknowledgments}

This research was part of USDA-ARS National Program 206: Manure and By-product Utilization; ARS Project 6657-13630-003-00D "Innovative Animal Manure Treatment Technologies for Enhanced Environmental Quality." The authors are grateful to Dr. Diana Rashash (NCCES, Jacksonville, NC) for her help in coordinating lagoon sampling work and Aprel Ellison and Laura Slice for their help with field and laboratory work.

\section{References}

Aneja, V.P., J.P. Chauhan, and J.T. Walker. 2000. Characterization of atmospheric ammonia emissions from swine waste storage and treatment lagoons. J. Geophys. Res. 105:11535-11545.

APHA, AWWA, and WEF. 1998. Standard methods for the examination of water and wastewater. 20th ed. American Public Health Assoc., American Water Works Assoc., and Water Environment Federation, Washington, DC.

Barker, J.C. 1996. Lagoon design and management for livestock waste treatment and storage. North Carolina Cooperative Extension Service Pub. No. EBAE 103-83, Greensboro and Raleigh, NC.

Barker, J.C., and J.P. Zublena. 1995. Livestock nutrient assessment in North Carolina. p. 98-106. In Proceedings of the 7th International Symposium on Agricultural and Food Processing Wastes. Am. Soc. Agric. Eng., St. Joseph, MI.

Bauer, P., A.A. Szogi, and M.B. Vanotti. 2007. Agronomic effectiveness of calcium phosphate recovered from liquid swine manure. Agron. J. 99:1352-1356.

Bicudo, J.R., L.M. Safley, and P.W. Westerman. 1999. Nutrient and sludge volumes in single-cell recycle anaerobic swine lagoons in North Carolina. Trans. ASAE 42:1087-1093.

Bowers, K.E., T. Zhang, and J.H. Harrison. 2007. Phosphorus removal by struvite crystallization in various livestock wastewaters. In International Symposium on Air Quality and Waste Management (Broomfield, Colorado). CD-Rom Proceedings of the Conference Pub. No. 701P0907cd ed. ASABE, St Joseph, MI.

Burns, R.T., L.B. Moody, F.R. Walker, and D.R. Raman. 2001. Laboratory and in-situ reductions of soluble phosphorus in swine waste slurries. Environ. Technol. 22:1273-1278.

Celen, I., J.R. Buchanan, R.T. Burns, R. Bruce Robinson, and D. Raj Raman. 2007. Using a chemical equilibrium model to predict amendments required to precipitate phosphorus as struvite in liquid swine manure. Water Res. 41:1689-1696.

Figueroa, L.A., and J. Silverstein. 1992. The effect of particulate organic matter on biofilm nitrification. Water Environ. Res. 64:728-733.

Fordham, A.W., and U. Schwertmann. 1977. Composition and reactions of liquid manure (gulle), with particular reference to phosphate: III. pH-buffering capacity and organic components. J. Environ. Qual. 6:140-144.

Grady, C.P.L., G.T. Daigger, and H.C. Lim. 1999. Biological wastewater treatment. 2nd ed. Marcel Dekker, New York.

Greaves, J., P. Hobbs, D. Chadwick, and P. Haygarth. 1999. Prospects for the recovery of phosphorus from animal manures: A review. Environ. Technol. 20:697-708.

House, W.A. 1999. The physico-chemical conditions for the precipitation of phosphate with calcium. Environ. Technol. 20:727-733.

Liberti, L., N. Limoni, A. Lopez, R. Passino, and G. Boari. 1986. The 10 $\mathrm{m}^{3} \mathrm{~h}^{-1}$ RIM-NUT demonstration plant at West Bari for removing and recovering $\mathrm{N}$ and $\mathrm{P}$ from wastewater. Water Res. 20:735-739.

Loehr, R.C., T.B.S. Prakasam, E.G. Srinath, and Y.D. Yoo. 1976. Development and demonstration of nutrient removal from animal wastes. U.S. Environmental Protection Agency, Washington, DC.

Loughrin, J.H., A.A. Szogi, and M.B. Vanotti. 2006. Reduction of malodorous compounds from a treated swine anaerobic lagoon. J. Environ. Qual. 35:194-199.

NCGeneral Assembly. 2007. Senate Bill 1465: Performance standards for animal waste management systems that serve swine farms; lagoon and sprayfield systems prohibited. General Assembly of North Carolina, Session 2007, Session Law 2007-523. Available at http://www.legislature.state.nc.us/ EnactedLegislation/SessionLaws/PDF/2007-2008/SL2007-523.pdf (verified 16 Oct. 2008).

Mallin, M.A. 2000. Impacts of industrial animal production on rivers and estuaries. Am. Scientist 88:26-37.

Nelson, N.O., R.L. Mikkelsen, and D.L. Hesterberg. 2003. Struvite precipitation in anaerobic swine lagoon liquid: Effect of $\mathrm{pH}$ and $\mathrm{Mg}: \mathrm{P}$ ratio and determination of rate constant. Bioresour. Technol. 89:229-236.

Parent, G., G. Bélanger, N. Ziadi, J. Deland, and J. Laperrière. 2007. Precipitation of liquid swine manure phosphates using magnesium 
smelting by-products. J. Environ. Qual. 36:557-567.

Peters, J., S.M. Combs, B. Hoskins, J. Jarman, J.L. Kovar, M.E. Watson, A.M. Wolf, and N. Wolf. 2003. Recommended methods of manure analysis. Univ.of Wisconsin Ext. Pub. A3769.

Pote, D.H., and T.C. Daniel. 2000. Analyzing for dissolved reactive phosphorus in water samples. p. 91-93. In G.M. Pierzynski (ed.) Methods of phosphorus analysis for soils, sediments, residuals, and water. Southern Coop. Series Bull. No. 396. Kansas State Univ., Manhattan, KS.

Randall, C.W., J.L. Barnard, and H.D. Stensel. 1992. Water quality management library- Volume 5/Design and retrofit of wastewater treatment plants for biological nutrient removal. Technomic Publishing Co., Lancaster, PA.

Reindl, J. 2007. Phosphorus removal from wastewater and manure through hydroxylapatite. An annotated bibliography. Available at http:// danedocs.countyofdane.com/webdocs/pdf/lwrd/lakes/hydroxylapatite. pdf (verified 14 Nov. 2007).

Schiffman, S.S., J.L. Bennett, and J.H. Raymer. 2001. Quantifications of odors and odorants from swine operations in North Carolina. Agric. For. Meteorol. 108:213-240.

Seckler, M.M., O.S.L. Bruinsma, and G.M. Van Rosmalen. 1996. Calcium phosphate precipitation in a fluidized bed in relation to process conditions: A black box approach. Water Res. 30:1677-1685.

Sherrard, J.H. 1976. Destruction of alkalinity in aerobic biological wastewater treatment. J. Water Pollut. Control Fed. 48:1834-1839.

Smil, V. 2000. Phosphorus in the environment: Natural flows and human interferences. Annu. Rev. Energy Environ. 25:53-88.

Sobsey, M.D., L.A. Khatib, V.R. Hill, E. Alocilja, and S. Pillai. 2001. Pathogens in animal wastes and the impacts of waste management practices on their survival, transport and fate. Chapter 17. p. 1-84. In White papers on animal agriculture and the environment. MidWest Plan Service (MWPS), Iowa State Univ., Ames, IA.

Sommer, S.G., and S. Husted. 1995. The chemical buffer system in raw and digested animal slurry. J. Agric. Sci. Cambridge 124:45-53.

Szogi, A.A., M.B. Vanotti, and P.G. Hunt. 2006. Dewatering of phosphorus extracted from liquid swine waste. Bioresour. Technol. 97:183-190.

Szogi, A.A., M.B. Vanotti, J.M. Rice, F.J. Humenik, and P.G. Hunt. 2004. Nitrification options for pig wastewater treatment. N. Z. J. Agric. Res. 47:439-448.

Tchobanoglous, G., and F.L. Burton. 1991. Wastewater engineering: Treatment, disposal, and reuse. Irwin/McGraw-Hill, Boston, MA.

Tomson, M.B., and L. Vignona. 1984. Precipitation of phosphate minerals in wastewater treatment systems. p. 386-399. In J.O. Nriagu and P.B. Moore (ed.) Phosphate minerals. Springer-Verlag, Berlin.

USDA-TVA. 1964. Superphosphate: Its history, chemistry, and manufacture. USDA-ARS, Washington, DC.

Valsami-Jones, E. 2001. Mineralogical controls on phosphorus recovery from wastewaters. Mineral. Mag. 65:611-620.

Vanotti, M.B., and P.G. Hunt. 2000. Nitrification treatment of swine wastewater with acclimated nitrifying sludge immobilized in polymer pellets. Trans. ASAE 43:405-413.

Vanotti, M.B., A.A. Szogi, and P.G. Hunt. 2003. Extraction of soluble phosphorus from swine wastewater. Trans. ASAE 46:1665-1674.

Vanotti, M.B., P.D. Millner, P.G. Hunt, and A.Q. Ellison. 2005a. Removal of pathogen and indicator microorganisms from liquid swine manure in multistep biological and chemical treatment. Bioresour. Technol. 96:209-214.

Vanotti, M.B., A.A. Szogi, and P.G. Hunt. 2005b. Wastewater treatment system. USA Patent 6893,567 B1. Date Issued: 17 May 2005.

Vanotti, M.B., A.A. Szogi, P.G. Hunt, P.D. Millner, and F.J. Humenik. 2007. Development of environmentally superior treatment system to replace anaerobic swine lagoons in the USA. Bioresour. Technol. 98:3184-3194.

Westerman, P.W., and J.R. Bicudo. 2000. Tangential flow separation and chemical enhancement to recover swine manure solids, nutrients, and metals. Bioresour. Technol. 73:1-11. 